DOI: 10.5824/1309-1581.2018.1.004.x

http://www.ajit-e.org/?menu=pages\&p=details_of_article\&id=333

Received :03.02.2018

Editorial Process Begin: 08.02.2018

Published: 12.02 .2018

\title{
Etik ve İnternet: BT Öğrencileri Üzerinde Güvenilirlik ve Geçerlilik Çalışması
}

Adem Özdemir, Aksaray Üniversitesi, Yönetim ve Bilişm Sistemleri Bölümü, https://orcid.org/0000-0002- 4031-389

Emin ïBiLi, Yrd. Doç. Dr., Aksaray Universitesi, Eğitim Fakültesi, Bilgisayar ve Öğretim Tekolojileri Eğitimi Bölümü, https://orcid.org/0000-0002-6186-3710

ÖZ Araştırmanın amacı bilişim bölümlerindeki lisans ve lisansüstü öğrencilerinin internet teknolojilerini etik kullanım düzeylerinin incelenmesidir. Araştırmanın örneklemini 2016-2017 eğitim-öğretim yılında üç farklı üniversitede öğrenim görmekte olan 491 öğrenci ile gerçekleştirilmiştir. Tarama modelinde gerçekleştirilen araştırmanın verileri araştırmacılar tarafından geliştirilen kişisel bilgi formu ve internet etik kullanım ölçeği oluşturmaktadır. İnternet kullanım etiği ölçeği maddelerinin geçerliliği ise Lawshe tekniği kullanılarak analiz edilmiştir. İnceleme sonucuna göre 0.05 anlamlılık düzeyinde geçerlilik oranı 0.73 olarak bulunmuştur. Ölçeğin kapsam geçerlilik indeksi 0.95 olarak bulunmuş. Ölçeğin tamamı için ise Cronbach Alfa güvenirlik katsayısı 0.916 bulunmuştur. Uzman görüşleri ve kapsam geçerlilik oranları doğrultusunda oluşturulan 38 maddelik ölçek formu Temel İlkeler, Dürüstlük, Güvenlik, Sağlıklı İnternet Kullanımı, Çevrimiçi Nezaket, Telif Hakkı olmak üzere altı boyuttan oluşmaktadır. Araştırmada elde edilen verilerin analizinde SPSS 22 programı kullanılmıştır. Araştırma sonucunda; kız öğrencilerin interneti etik kullanım düzeylerinin daha yüksek olduğu, ailelerinin gelir düzeyi arttıkça interneti etik kullanım düzeylerinin azaldığı ve öğrencilerin web tasarımı ve programlama düzeyleri arttıkça interneti etik kullanım düzeylerinin azaldığını bulunmuştur. Ayrıca öğrencilerin bölümlerine, interneti kulanım amaçlarına ve internet kullanım sürelerine göre öğrencilerin internetin etik kullanım düzeylerinin farklılaştığı bulunmuştur.

Anahtar Sözcükler: Etik, İnternet Etiği, İnterneti Etik Kullanım Düzeyi

\section{Investigation of Internet Ethical Usage Levels of the Students of Information Technologies in Terms of Different Variables}

ABSTRACT The aim of the research is to examine the ethical use levels of Internet technologies of undergraduate and graduate students in the information departments. The sample of the study was conducted with 491 students studying at three different universities during the academic year of 2016-2017. The data of the research conducted in the screening model were obtained from the personal information form developed by the researchers and from the internet ethical usage scale. The validity of internet use scale items was analyzed using Lawshe technique. The validity of the scale was 0.73 and the Cronbach Alpha reliability coefficient was 0.916 for the scale. The 38 -item scale form formed in line with expert opinions and coverage validity consists of six dimensions including Basic Principles, Honesty, Security, Healthy Internet Usage, Online Courtesy, Copyright. SPSS 22 program was used in the analysis of the data obtained in the research. As a result of the research; it was found that ethnic use levels of females were higher than that of males, ethical usage levels of internet decreased as the income level of the students' families increased and as the web design and programming levels of the students increased, the internet ethical usage levels decreased. In addition, it was found that ethical usage levels of internet according to students' 
sections are significant in terms of all dimensions. According to internet usage aims and internet usage periods, students' ethical usage levels of internet have been found different.

Keywords: Ethic, Internet Ethics, Internet Ethical Use Level

Not: Bu çalışma 11-13 Ekim 2017 tarihleri arasında gerçekleştirilen 5. Uluslararası Öğretim Teknolojileri ve Öğretmen Eğitimi Sempozyumunda sözlü bildiri olarak sunulmuştur.

\section{GİRIŞ}

Bilişim teknolojileri günden güne bireylerin günlük yaşantılarına daha fazla dâhil olmakta ve hayatlarını oldukça kolaylaştırmaktadır. Bugün insanlar geçmişe göre daha fazla iletişim kurabilmekte, bilgi edinebilmekte ve elde ettikleri bu bilgileri kolayca depolayıp başkalarına iletebilmektedirler (Cerrah, 2001). Bilgi ve iletişim teknolojilerinin (BiT) toplumsal hayatın her anında ve alanında kullanılmasının yaygınlaşması ile birlikte eticaret, e-devlet, e-öğrenme gibi web tabanlı sistemlere yönelim artmış ve kullanıcı sayısı hızla artmıştır (Dedeoğlu, 2006). İletişimden ulaşıma, eğitim-öğretimden ekonomiye kadar oldukça geniş alanda kullanılan bilgisayarlara her geçen gün artarak bağımlı hale geldikçe, belki daha önce akla dahi gelmeyen etik problemlerin meydana geldiği gözlenmiştir (Dedeoğlu, 2001). Bunların başında; yazılımların lisans alınmaksızın kullanılması, sanatçıların eserlerine yasadışı yollarla web ortamından ulaşılması, hırsızlık, kredi kartı dolandırıcılığı, virüslü yazılımlarla sistemlere zarar verme gibi problemler gelmektedir. Ayrıca bilgi çalma, bir sisteme uzaktan erişim sağlayarak etkisiz hale getirerek bir grubu ya da kurum/kuruluşlarını zarara uğratmak, web ortamında yer alan fikri yapıtların kolaylıkla kopyalanarak paylaşılması gibi etik dışı davranışlar da gün geçtikçe artmıştır (Dedeoğlu, 2006). Bu doğrultuda yapılan araştırmalarda kişiler, internet teknolojilerinin gelişmesi ile birlikte kendilerini fizyolojik ve mental yönlerden geliştirerek geçmişte düşünemedikleri etik dışı davranışları rahatlıkla yapabildiklerini belirtmektedirler.

Gelişen internet teknolojileri ile meydana gelen etik dışı davranışlar birçok sorunlara neden olmakla birlikte yeni etik dışı davranışları da teşvik edici özelliği bulunmaktadır (Çelen, 2012). Öyle ki çağımızda; küçük yaşlardan itibaren kişiler kendilerini çevrelerindeki insanlardan soyutladıkları için diğer kişilerle iletişim kurma noktasında sorunlar yaşamaktadırlar. Çünkü akıllı telefonlar, tabletler, bilgisayarlar, internet ve diğer bilişim teknolojilerinin sundukları olanaklarla birlikte bireyler kendi çıkarlarını gözeten, başkalarının haklarına saygı duymayan kimliğe bürünmüş ve bu durumu da etik kurallar çerçevesinde görür hale gelmişlerdir (Özaydın, 2010). Başka bir ifade ile internet ve bilişim teknolojilerindeki gelişmeler ve değişimler insanlar arasında sanal bir mesafe 
oluşturmaktadır. Böylece etik duyarlılık ortadan kalkarak internet ortamında etik dışı davranışa maruz kalan bireyler ile empati kurmak zorlaşmaktadır. Ayrıca kişiler kendi çıkarlarını başkalarının kaygılarının önünde bulundurarak sosyal paylaşım ortamlarında başkalarını rahatsız edici şekilde davranmakta, yasadışı yollardan müzik, video, oyun ve yazılımlar indirmektedirler (Torun, 2007). Bütün bu sorunların çözüme kavuşması için bireylerin ve kurumların katkı sağlaması oldukça önem arz etmektedir. Her ne kadar bu konu bilişim uzmanlarının alanı gibi görünse de toplumun hemen hemen bütün kesimindeki bireyler, herhangi bir yolla bilişim teknolojilerini kullandıkları için meydana gelen etik problemlerin giderilmesinde, gerekli olan anlayışta ve iş birliğinde bulunmak zorundadırlar (Dedeoğlu, 2001). YBS ve BÖTE bölümü öğrencilerinin ise yarının iş dünyasında ve eğitim camiasında yer alacakları düşünüldüğünde, öğrencilerin internet teknolojilerinin kullanımında etik ilkelere bağlı kalmaları, etik kullanım konusunda farkındalık oluşturmaları gibi anlayışlarının geliştirilmesi oldukça önem arz etmektedir. Bu sebeple araştırmanın amacı YBS ve BÖTE bölümü öğrencilerinin internet teknolojileri kullanımındaki etik davranış düzeylerinin belirlenmesi ve etik kullanım düzeylerini etkileyen faktörlerin belirlenmesidir. Bu kapsamda aşağıdaki araştırma sorularına cevap aranmıştır.

\section{Araştırma Soruları}

Yönetim Bilişim Sistemleri (YBS) ve Bilgisayar ve Öğretim Teknolojileri Eğitimi (BÖTE) bölümü öğrencilerinin interneti etik kullanım düzeyleri nasıldır?

\section{Alt Problemler}

1. YBS ve BÖTE bölümündeki öğrencilerin interneti etik kullanım düzeyleri cinsiyete göre anlamlı fark göstermekte midir?

2. YBS ve BÖTE bölümündeki öğrencilerin interneti etik kullanım düzeyleri ailelerinin gelir düzeylerine göre anlamlı fark göstermekte midir?

3. YBS ve BÖTE bölümündeki öğrencilerin interneti etik kullanım düzeyleri internete bağlı kalma sürelerine göre anlamlı fark göstermekte midir?

4. YBS ve BÖTE bölümündeki öğrencilerin interneti etik kullanım düzeyleri internet kullanım beceri düzeylerine göre anlamlı fark göstermekte midir?

5. YBS ve BÖTE bölümündeki öğrencilerin interneti etik kullanım düzeyleri web tasarımı ve program yazabilme beceri düzeylerine göre anlamlı fark göstermekte midir?

6. YBS ve BÖTE bölümündeki öğrencilerin interneti etik kullanım düzeyleri interneti kullanım amaçlarına göre anlamlı fark göstermekte midir? 
7. YBS ve BÖTE bölümündeki öğrencilerin interneti etik kullanım düzeyleri bölümlerine göre anlamlı fark göstermekte midir?

\subsection{Internet Etik Kullanım Boyutları}

Bilişim teknolojileri her gün gelişmekte ve bireylere sunduğu imkânlarda bu doğrultuda gelişmektedir. Ancak bu gelişmeler beraberinde etik sorunları da getirmiştir ve bu sorunların ilk sırasında ise mahremiyet vardır. Mahremiyet kavramı ilk olarak 1890 yılında Amerikalı yargıç Brandeis tarafından "bireyin yalnız bırakılma hakkı" şeklinde açıklanmıştır. Bugüne kadar mahremiyet kavramı birçok kez konuşulmuş; fakat sınırları net olarak belirtilememiştir. Sınırların belirlenmemesinin en önemli sebebi ise özgürlüklerin geniş olması ve sınırlandırılamamasıdır (Manning, 1997; Kavza, 2010).

Bir diğer önemli konu ise fikri mülkiyet, telif hakkıdır. Fikri mülkiyet, kişinin düşünce gücü ile oluşturduğu ürünlerin mülkiyetidir. Oluşturulan ürünler bir kitap, bir tablo, bir icat veya bir bilgisayar yazılımı olabilir. Önemli olan fikrin dışa vurulmasıdır. Telif hakkı ise fikri mülkiyeti koruyan hakların bütünüdür. Edebi veya diğer eser (bilgisayar yazılımı dahil) sahiplerinin haklarının korunmasını sağlayan ve haklarını belirten hukuki bir terimdir (Türk Patent Enstitüsü, 2013).

Meydana gelen sorunlardan bir diğeri ise çevrimiçi nezakettir. Çevrimiçi nezaket alan yazında "ifade hürriyeti", "düşünce hürriyeti”, "düşünme hürriyeti”, "düşünceyi açıklama özgürlüğü", "fikir açıklama özgürlüğ̈̈", "konuşma özgürlüğü", “iletişim özgürlüğü" olarak ifade edilmiştir. İfade özgürlüğü, belirli bir düşüncenin beyan edilmesi ve çevresinde birleşilmesi hakkını ifade etmektedir (Dülger, 2004). Kişisel düşüncelerin ifadesi çerçevesinde, dile getirme, savunma, tanıtma, eleştirme, reddetme, çağrıda bulunma, ikna etme, açıklama, yayma, yayımlama, propaganda yapma gibi çeşitli şekillerde ifade edilebilir. İfade özgürlügüüü gerçekleştirirken söz, yazı, resim, müzik, sinema, radyo, televizyon, internet vb. her türlü araç kullanılabilir. Ayrıca kullanılan dil de ifade özgürlüğünün ayrılmaz bir parçasıdır (Selçuk, 2005; Baloğlu, 2006). Ancak hangi beyanların ifade özgürlüğü çerçevesinde olduğu ve bu beyanların sınırlarının neler olduğu konusu en çok tartışılan konulardır. Bu tartışma konularından bir diğeri ise; müstehcenlik, nefret, ırkçılık içeren propagandalar, ticari reklamcılık ve tehditkâr ifadelerin ifade özgürlüğü kapsamındaki yeridir. Öyle ki; müstehcen ifadeler, en liberal toplumlarda dahi koruma altında değildir. Birçok ülkede bu tip ifadeler ahlaki ya da dini 
sebeplerden dolayı yasaklanmıştır. Amerika'da müstehcen yayınlara karşı tepkiler her geçen gün giderek artmaktadır (Arslan, 2003). Bunun için müstehcen yayınların üretimi ve dağıtımı yasa dışı sayılmaktadır. On sekiz yaşından küçüklere "müstehcen ve ahlak dışı" mesajlar gönderilmesi cezai yaptırıma tabidir (Karagöz, 2004). Müstehcenlik, Türkiye'de de 5237 sayılı Yeni Türk Ceza Kanunu kapsamında genel ahlaka karşı suçlar kapsamında bulunmaktadır (Türk Ceza Kanunu, 2004).

Öğrencilerin internet teknolojilerini etik kullanımı ve cinsiyet, etik ilkeler arasındaki ilişkiye yönelik yapılan araştırmalar incelendiğinde, Haines ve Leonard (2007) çalışmalarında, cinsiyet ve benlik algıları etik kararlar almalarında en önemli etkiye sahip olduğu sonucuna ulaşmışlardır. Ayrıca benlik algıları düşük seviyede olan kişilerin şüpheli davranışlar sergileyen kişilerle tartıştıktan sonraki fikirleri ve inanışları oldukça fazla bir şekilde değiştiği sonucuna ulaşmışlardır. Kiera ve Cronan (1998); kişilerin etik davranışlarındaki sosyal çevreleri, inançları, iş çevreleri, şahsi çevreleri, yasal çevreleri, kişisel değerleri ve ahlaki sorumlulukları gibi faktörlerin etkilerini incelemişlerdir. Çalışmaya katılan kişilerin etik konulardaki düşüncelerini belirtmelerindeki en güçlü faktörün kişisel değerler olduğunu ifade etmişlerdir. Bilgisayar teknolojileri kullanımlarında karşılaşılan etik ile ilgili durumlarda ise bayanların etik davranışlarda bulunmaya daha çok özen gösterdiklerini saptanmıştır. Mason (1986), etik dışı davranışları fikri mülkiyet, gizlilik, erişim ve doğruluk faktörleri doğrultusunda meydana geldiğini belirtmiştir. Daha sonraki çalışmalarında ise, bu faktörlere ek olarak bilgisayarların toplumsal etkileri, güvenlik, kalite, bilgi ve ağ doğruluğu gibi faktörlerinin de etik dışı davranışların meydan gelmesinde etkisinin bulunduğunu belirtmiştir.

Öğrencilerin internet teknolojilerini etik kullanımı ve sınıf düzeyleri, bölümleri, telif hakkı arasındaki ilişkiye yönelik yapılan araştırmalar incelendiğinde, Perry (2010) ise yapmış olduğu çalışmada birinci sınıf öğrencilerinin \%28'i, diğer sınıflardakilerin de \%80'i kopyala-yapıştır yapmanın intihal olduğunu belirtmiştir. Sadece \%24'ü kelime kopyalamanın, \%23’ü de kaynakça göstermeden yapılan ödevlerin bu konu kapsamına girdiğini belirtmişlerdir. Ayrıca öğrenciler kendilerine verilen ödevler çok zor olduğunda, teslim tarihi yakın olduğunda, başarısız olma durumunda ve yakalanmama düşüncesinin hâkim olduğu durumlarda intihal yaptıklarını belirtmişlerdir. Ersoy ve Özden (2011) çalışmalarında, sınıf öğretmenliği bölümünde eğitim alan öğrencilerin ödevlerini hazırlarken intihal yapmalarında öğretim elemanının etkisini incelemişlerdir. Çalışmalarının sonucunda ise; öğrencilerin yarısına yakını ödevlerin kopyala yapıştır ile hazırlanamayacağını savunmaktadır. Diğer yarısı ise internetteki hazır bir ödevi düzenleyerek yeniden hazırlanabileceği görüşünde olduğu sonucuna ulaşmışlardır. Kuzu 
ve Becit (2008) çalı̧̧malarında, 29 üniversitenin BÖTE bölümlerinde bilgisayar etiği dersinin bulunup bulunmadığını ve bulunuyorsa işleyiş ve içeriğinin nasıl olduğunu öğrenmeyi hedeflemişleridir. Yapmış oldukları çalışmanın sonucunda ise; BÖTE bölümünde etik dersine yeterince yer verilmediği ve zorunlu ders olarak işlenmediği sonucuna ulaşmışlardır.

Öğrencilerin internet teknolojilerini etik kullanımı ve ailelerinin gelir düzeyi, internet teknolojileri kullanım etiği arasındaki ilişkiye yönelik yapılan araştırmalar incelendiğinde, Torun (2007) yapmış olduğu çalışmasında öğrencilerin ailelerinin gelir seviyesinin arttıkça, interneti etik kullanım tutumlarının olumsuzlaştığı sonucuna ulaşmıştır. Büyükfiliz (2016) ve Durak Batıün ve Kılıç (2011) yapmış oldukları çalışmalarında ailelerin gelir seviyesi üst sosyoekonomik düzeyde olanların, düşük ve orta sosyoekonomik düzeyde olanlara göre daha fazla problemli internet kullandıkları sonucuna ulaşmıştır. Zeybek (2011) çalışmasında, erkek öğrencilerin veya ekonomik durumu iyi olan öğrencilerin etik dışı davranışlarda bulundukları sonucuna ulaşmıştır. Lau ve Yuen (2014) araştırmasında erkeklerin kızlara göre ve sosyoekonomik düzeyi daha düşük olanların yüksek olanlara oranla daha fazla etik dışı davranış sergilediklerini saptamışlardır. Kazaskeroğlu, Özpınar ve Öz (2010) çalışmalarında, üniversite öğrencilerinin internet ortamında bilgiye erişimlerinde ve paylaşımlarında göstermiş oldukları etik davranışları incelemişlerdir. Çalışmayı İstanbul Ticaret Üniversitesinde eğitim alan 400 öğrenci ile gerçekleştirmişlerdir. Çalışmanın sonucunda ise; kişilerin etik dışı davranışlara yönlenme sebebinin başka kişilerin zarar görmeyeceği düşüncesi ve yakalanmama düşüncesi olduğu sonucuna ulaşmışlardır.

Öğrencilerin internet teknolojilerini etik kullanımı ve güvenlik, siber zorbalık arasındaki ilişkiye yönelik yapılan araştırmalar incelendiğinde, Arıcak (2009) çalışmasında, erkeklerin bayanlara göre daha fazla siber zorbalıkta bulunduğunu ve düşmanlık hissi belirten duygular psikolojik belirtilerin siber zorbalığı etkileyen temel değişken olduğu sonucuna ulaşmıştır. Çetinkaya (2010) ilköğretimde okuyan erkek öğrencilerin kız öğrencilere göre daha fazla siber zorbalıkta bulunduğunu ve aynı zamanda da siber zorbalığa maruz kaldığı sonucuna ulaşmışır. Takemura, Tanaka ve Matsuura (2011) çalışmalarında Japon şirketlerinde çalışan kişilerin bilgi güvenliği farkındalık düzeyleri ile öznitelikleri arasındaki ilişkiyi araştırdıkları araştırmasında, kişisel özelliklerin farkındalık düzeylerini etkilediğini ve bu durumunda bilgi güvenliği üzerinde de etkisinin olduğu sonucuna ulaşmışlardır. Baker ve Kavşut (2007) çalışmalarında, lise öğrencilerinin siber zorbalık deneyimlerini, internet kullanım sıklığını incelemeyi amaçlamışlardır. Çalışma yaşları 14 
ile 19 arasında olan 228 lise öğrencisi ile gerçekleştirilmiştir. Araştırmanın sonucunda ise, erkeklerin kızlara göre hem daha çok siber zorbalık yaptıkları hem de siber zorbalığa maruz kaldıkları sonucuna ulaşmışlardır. Ayrıca internet kullanımı siber zorbalık yapmayı ya da maruz kalma arasında pozitif bir yönde ilişki var iken; okul türü, yaş, sınıf, ekonomik gelir değişkenlerinin ilişkisinin olmadığı sonucuna ulaşmışlardır.

\section{ARAŞTIRMANIN YÖNTEMI}

\subsection{Araştırma Modeli}

$\mathrm{Bu}$ çalışmanın amacı BÖTE ve YBS bölümü öğrencilerinin internet teknolojilerini etik kullanım düzeylerinin ve farklı değişkenlerin internet etik kullanım düzeylerine etkisinin incelenmesidir. Bu doğrultuda bireylerin cinsiyet, sınıf düzeyi, ailelerinin gelir durumu, internete bağlı kalma süreleri, internet kullanım beceri düzeyleri, kişisel bilgisayara sahip olup olmama, web sayfası tasarlayabilme düzeyleri, program yazabilme değişkenleri açısından farklılı̆̆ın olup olmadığını belirlemek için ilişkisel tarama modeli ile incelenmiştir (Karasar, 2004).

\subsection{Evren ve Örneklem}

Araştırmanın evrenini BÖTE ve Yönetim Bilişim Sistemleri bölümü öğrencileri oluşturmaktadır. Araştırmada amaçlı örnekleme yoluna gidilmiştir. Araştırmanın örneklemini üç farklı taşra devlet üniversitesinde öğrenim görmekte olan Yönetim Bilişim Sistemleri ve Bilgisayar ve Öğretim Teknolojileri Eğitimi bölümlerinde öğrenim gören 226 YBS ve 255 BÖTE bölümü öğrencisi oluşturmaktadır.

\subsection{Veri Toplama Araçları}

Araştırmanın verileri araştırmacılar tarafından geliştirilen kişisel bilgi formu ve internet etik kullanım ölçeği oluşturmaktadır. Kişisel bilgi formunda bireylerin cinsiyet, sınıf düzeyi, ailelerinin gelir durumu, internete bağlı kalma süreleri, internet kullanım beceri düzeyleri, kişisel bilgisayara sahip olup olmama, web sayfası tasarlayabilme düzeyleri, program yazabilme değişkenleri yer almaktadır. İnternet kullanım ölçeği ise Likert Tipinde oluşturulmuş ve (1) Hiçbir zaman (2) Çok nadir (3) Bazen (4) Çoğu zaman (5) Her zaman şeklindedir. Ayrıca bilişim etiği boyutları oluşturulurken Mason (1986) ve Fidan'ın (2016) yapmış oldukları çalışmalardaki bilişim etiği boyutlarından faydalanılmıştır. Araştırma sonucunda "Temel İlkeler", "Dürüstlük, Güvenlik", "Sağlıklı İnternet Kullanımı", "Çevrimiçi Nezaket" ve "Telif Hakkı" boyutları belirlenmiştir. Bu ölçekte temel ilkeler boyutuna ait 11 madde, dürüstlük boyutuna ait 7 madde, güvenlik boyutuna 
ait 6 madde, sağlıklı internet kullanımı boyutuna ait 6 madde, çevrimiçi nezaket boyutuna ait 5 madde ve telif hakkı boyutuna ait 3 madde olmak üzere toplam 38 madde yer almaktadır.

\section{4. Ölçeğin Geliştirilmesi}

Ölçeğin geliştirilmesi aşamasında Mason'un (1956) Bilgi Çağının Dört Etik Sorunu çalışmasında belirttiği etik sorunlar ve Fidan'ın (2016) Bilişim Etiği Boyutlarına Göre Bilişim Teknolojileri ve Yazılım Dersi Öğretim Programı Kazanımlarının İncelenmesi çalışmasında belirttiği etik boyutlar araştırmanın temel boyutları olarak esas alınmıştır. Madde soru havusu oluşturulurken ise ulusal ve uluslararası düzeyde Türkiye Bilişim Derneği (TBD), Türkiye Bilişim Vakfı (TBV), Türkiye Bilişim Sektörü Derneği (TÜBİDER), Türkiye Etik Enstitüsü (BEE) gibi kuruluşlarca hazırlanan bilişim ve internet etiğine yönelik belge, sözleşme, yönetmelik vb. kaynaklardan faydalanılmıştır. Toplam127 maddeden oluşan ilk soru havuzu on uzman tarafından incelenmiştir. Daha sonra 131 kişi ile gerçekleştirilen pilot çalışmada, öğrencilerden alınan geri dönüşler ve gözlemler sonucunda ölçek formunda ve soru havuzunda düzenleme yapılmış ve nihai ölçek 89 sorudan oluşmuştur.

\subsection{Geçerlik Analizi}

Maddelerin geçerliliği Lawshe tekniği kullanılarak analiz edilmiştir. Lawshe (1975) tekniğinde, en az 5 en fazla 40 kişiden oluşan uzman kişiler tarafından incelenerek görüşleri doğrultusunda geçerlilik oranları elde edilmektedir. Oluşturulan taslak maddelerini uzmanlar "gerekli", "yararlı/yetersiz", "gereksiz" olmak üzere üç seçenek olarak değerlendirilmişlerdir. Ölçek maddeleri üç farklı üniversitede görev yapan: 1 Profesör, 3 Doçent, 6 Yardımcı Doçent olmak üzere 10 uzman kişi tarafından incelenmiştir. İnceleme sonucuna göre 0.05 anlamlılık düzeyinde geçerlilik oranı 0.73 olarak bulunmuştur. Hesaplama sonucu, uzman görüşleri ve kapsam geçerlilik oranları doğrultusunda 38 maddelik ölçek formu üzerinden analizler yapılmıştır. Bu doğrultuda ölçek maddelerinin KGİ (I-CVI) 0.8 ile1.0 aralığında değişmektedir. Ölçeğin kapsam geçerlilik indeksi 0.95 olarak bulunmuş. Bu sonuçlara göre ölçeğin kabul edilebilir düzeyde olduğu söylenilebilir. 


\subsection{Güvenirlik Analizi}

İnternet etik davranışları ölçeğinin boyutlara göre Cronbach Alfa güvenirlik katsayıları, temel ilkeler boyutu için 0.959; dürüstlük boyutu için 0.958; güvenlik boyutu için 0.934; sağlıklı internet kullanımı boyutu için 0.871; çevrimiçi nezaket boyutu için 0.805; telif hakkı boyutu için 0.800 bulunmuştur. Ölçeğin tamamı için ise Cronbach Alfa güvenirlik katsayısı 0.916 bulunmuştur. Bu sonuçlar neticesinde ölçekte yer alan maddelerin geçerliliklerinin yüksek olduğu ve güvenirlik bakımından öğrencilerin interneti etik kullanım düzeylerini ölçemeye yönelik maddeler olduğu söylenebilir.

\subsection{Faktör Analizi Uygulanması ve Bulgular}

Uygulanan faktör analizinde temel bileşenler yöntemi ve varimax döndürme yöntemi uygulanmıştır. Analiz sonucunda öz değerleri (eigenvalue) birin (>1) üzerinde olan ve toplam varyansın \%72.691'ini açıklayan 6 faktör elde edilmiştir. Temel İlkeler faktörü toplam varyansın \%29.15'ini, Dürüstlük faktörü toplam varyansın \%12.17'sini, Sağlıklı Internet Kullanımı faktörü toplam varyansın \%9.61'ini, Çevrimiçi Nezaket faktörü toplam varyansın \%9.56'sını, Telif Hakkı faktörü toplam varyansın \%7.1'ini ve Güvenlik faktörü toplam varyansın \%5.10'unu açıklamaktadır.

\subsection{Verilerin Analizi}

Ölçekte yer alan verilerin analizi için SPSS 22 paket programı kullanılmıştır. Alt problemlerin istatistiksel analizleri yapılırken betimleyici analizlerden ve istatistikten yararlanılmıştır. Bu analizler için cinsiyet, internetin kullanım amaçları bağımsız değişkenleri ile internet etiği ölçeğine ilişkin görüşlerinin aritmetik ortalama puanları ve standart sapmaları dikkate alınarak ilişkisiz (bağımsız) örneklem için T testi (Independent samples $\mathrm{t}$ test) yapılmıştır. Öğrencilerin sınıf düzeyleri, ailelerinin gelir düzeyleri, internete bağlı kalma süreleri, internet kullanım düzeyleri için ise yine internet etiği ölçeğinden elde edilen aritmetik ortalama puanları ve standart sapmaları dikkate alınmıştır.

\section{BULGULAR}

Araştırmanın bu bölümünde veri toplama araçları ile elde edilen verilerin her bir alt probleme yönelik olarak istatistiksel teknikler ile yapılan çözümleme sonuçlarına yer verilmiştir. 


\subsection{Cinsiyetin İnternetin Etik Kullanım Düzeylerine Olan Etkisi}

İnternetin etik kullanımında cinsiyetin bir rol oynayıp oynamadığına aritmetik ortalama ve bağımsız örneklemler t-testi ile bakılmış ve sonuçlar Tablo 1' de verilmiştir.

Tablo 1. Öğrencilerinin Internetin Etik Kullanım Düzeyleri Alt Boyutuna Yönelik Internet Etik Kullanım Düzeylerinin Cinsiyete Göre t Testi Sonuç Özeti.

\begin{tabular}{|c|c|c|c|c|}
\hline \multirow[t]{2}{*}{ Etik Boyutlar } & \multicolumn{2}{|c|}{ Ortalamalar $(\bar{X})$} & \multirow[t]{2}{*}{$\mathbf{t}$} & \multirow[t]{2}{*}{$\mathbf{p}$} \\
\hline & Kadın(N=244) & Erkek(N=247) & & \\
\hline Temel ilkeler & 37.29 & 36.69 & 4.34 & 0.67 \\
\hline Dürüstlük & 24.84 & 23.73 & 1.19 & 0.23 \\
\hline Güvenlik & 19.87 & 19.56 & 3.94 & 0.69 \\
\hline Sağlıklı Internet Kullanımı & 20.65 & 19.97 & 1.10 & 0.27 \\
\hline Çevrimiçi Nezaket & 17.45 & 16.57 & 1.73 & 0.83 \\
\hline Telif Hakkı & 9.53 & 8.55 & 3.09 & $0.02^{*}$ \\
\hline Toplam & 129.62 & 125.08 & 1.71 & 0.88 \\
\hline
\end{tabular}

Tablo 1'de yer alan verilere göre öğrencilerinin telif hakkı boyutunda bayan ve erkek öğrenciler arasında anlamlı bir farklılığın olduğu görülmektedir $\left[\mathrm{t}_{(491)}=3.09, \bar{X}_{\text {Bayan:244 }}=9.53\right.$, $\left.\left.\bar{X}_{\text {Erkek:247 }}=8.55, \mathrm{p}<0.05\right)\right]$. Diğer boyutlar açısından ise kız ve erkek öğrenciler arasında anlamlı bir farklılık bulunmamıştır.

\section{2 Öğrencilerin Internet Etik Kullanımlarının Ailelerin Gelir Düzeylerine Göre İncelenmesi}

Araştırmaya katılan öğrencilerin ailelerinin gelir düzeyine göre internetin etik kullanım ölçeğine ilişkin ortalamaları incelendiğinde ailelerin gelir seviyesi arttıkça öğrencilerin sağlıklı internet kullanım düzeylerinde azalma olduğu görülmektedir $\left(\bar{X}_{1500 \text { TLaltı }}=21.48\right.$, $\left.\bar{X}_{2500 t l v e u ̈ z e r i}=19,70, F(2,488)=3.91\right)$. Diğer boyutlar açısından ise ailenin ekonomik durumunun istatistiksel açıdan anlamlı bir etkisinin olmadığı görülmektedir. 


\section{3 Öğrencilerin Günlük Internet Kullanım Sürelerine Göre Etik Internet} Kullanım Düzeylerinin İncelenmesi

Araştırmaya katılan öğrencilerin internete günlük bağlı kalma sürelerine ilişkin ortalama incelendiğinde, $\mathrm{p}<0.05$ anlamlılık düzeyinde sağlıklı internet kullanımı boyutunda $\left(\bar{X}_{1 \text { saat }}\right.$ $\left.=18.46 \bar{X}_{\text {5saatveüzeri }}=16.27, \mathrm{~F}(4,486)=3.01\right)$ ve güvenlik boyutunda $\left(\bar{X}_{1 \text { saat }}=17.32 \bar{X}_{5 \text { saatveüzeri }}\right.$ $=19.80, \mathrm{~F}(4,486)=2.67)$ anlamlı bir farklılık görülmektedir. Güvenlik boyutunda öğrencilerin internete bağlı kalma süreleri arttıkça interneti etik kullanımları arttığı görülmüştür. Ancak sağlıklı internet kullanımı boyutunda ise öğrencilerin internete bağlı kalma süreleri yükseldikçe interneti etik kullanım düzeylerinin azaldığı belirlenmiştir.

\section{4 Öğrencilerin Web Tasarımı ve Programlama Düzeylerine Yönelik} Özalgılarının Internetin Etik Kullanım Düzeylerine Etkisi

Öğrencilerin web sayfası tasarlayabilme ve programlama becerilerine yönelik özalgılarının internet etik kullanım düzeylerine olan etkisine yönelik görüşlerinin ortalamaları ve standart sapmaları arasında anlamlı bir fark olup olmadığını görmek için Varyans analizi yapılmıştır. $\mathrm{Bu}$ sonuçlara göre öğrencilerin interneti etik kullanım düzeyleri $\mathrm{p}<0.05$ anlamlılık düzeyinde öğrencilerin web sayfası tasarlayabilme düzeyleri ve programlama becerileri ile interneti etik kullanımlarına yönelik sadece telif hakkı boyutunda FWeb Tasarımı $(4,486)=3.00, \mathrm{~F}$ programlama becerisi $(4,486)=2.41$ anlamlı bir farklılık görülmektedir. Oluşan farklılı̆̆ın hangi gruplar arasında olduğunu belirlemek için Bonferroni testi ile Post Hoc karşılaştırılması yapıldığında telif hakkı boyutunda program yazabilme ve web sayfası tasarlayabilme becerisi hiç olmayanlar ile iyi olanlar arasında anlamlı bir farklılık görülmektedir ve bu farklılık öğrencilerin becerileri arttıkça interneti etik kullanım düzeylerinin azaldığını göstermektedir.

\section{5 Öğrencilerin İnterneti Etik Kullanımları ve Bölümleri Arasındaki İlişki}

Araştırmaya katılan öğrencilerin bölümlerine ilişkin ortalamalar incelendiğinde, $p<0.05$ anlamlılık düzeyinde tüm boyutlar için anlamlı bir farklılık görülmektedir. Aynı zamanda BÖTE bölümü öğrencilerinin interneti etik kullanım düzeyleri Sağlıklı Internet Kullanımı $\left.\left[\mathrm{t}_{(491)}=2.65, \bar{X}_{\text {YBS:226 }}=19.42, \bar{X}_{\text {вӦтЕ:265 }}=21.05, \mathrm{p}<0.05\right)\right]$ ve Çevrimiçi Nezaket boyutlar1 [ $\mathrm{t}_{(491)}=4.91$, $\bar{X}$ YвS:226=15.68, $\bar{X}$ вӧтЕ:265=18.13, p<0.05)] açısından ortalama puanlar1 YBS bölümü öğrencilerine göre daha yüksek olduğu görülmektedir. YBS bölümü öğrencilerinin de Temel ilkeler boyutu [ $\left.\mathrm{t}_{(491)}=6.25, \bar{X}_{\text {YBS:226 }}=41.49, \bar{X}_{\text {вӧтЕ:265 }}=33.15, \mathrm{p}<0.05\right)$ ], Dürüstlük boyutu $\left.\left[\mathrm{t}_{(491)}=6.22, \bar{X}_{\text {ҮВS:226 }}=27.29, \bar{X}_{\text {вӧТЕ:265 }}=21.70, \mathrm{p}<0.05\right)\right]$, Güvenlik boyutu $\left[\mathrm{t}_{(491)}=6.43, \bar{X}_{\text {ҮВS:226 }}=22.31\right.$, 
$\left.\left.\bar{X}_{\text {вӦтв:265 }}=17.49, \mathrm{p}<0.05\right)\right]$, Telif hakkı boyutu [ $\left.\left.\mathrm{t}_{(491)}=5.92, \bar{X}_{\text {ҮВs:22 }}=10.02, \bar{X}_{\text {вÖтЕ:265 }}=8.19, \mathrm{p}<0.05\right)\right]$ açısından BÖTE bölümü öğrencilerine göre ortalama puanlarının yüksek olduğu görülmektedir.

\section{6 Öğrencilerin İnterneti Etik Kullanımları ve İnterneti Kullanım Amaçları} Arasındaki İlişki

Araştırmaya katılan öğrencilerin interneti etik kullanımları ve interneti kullanım amaçları arasında ki ilişkiyi belirlemek için bağımsız $\mathrm{t}$ testi yapılmıştır. Elde edilen bulgular neticesinde, Sosyal ağlarda paylaşımda bulunma [ $\mathrm{t}_{(491)}=1.11, \bar{X}_{\text {hayr: } 148}=129.60, \bar{X}_{\text {Evet:343 }}=126.35$,

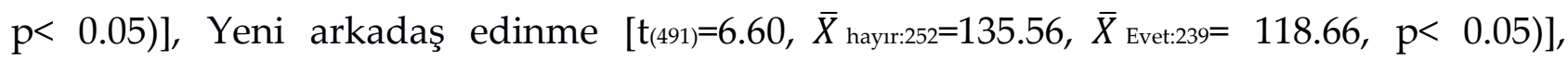
Arkadaşlarla iletişim kurma durumları $\left.\left[\mathrm{t}(491)=2.86, \bar{X}_{\text {hayrr.54 }}=138.11, \bar{X}_{\text {Evet:451 }}=126.00, \mathrm{p}<0.05\right)\right]$ arasında anlamlı bir ilişki olduğu görülmektedir. Ayrıca interneti sosyal ağlarda paylaşımda bulunma için seçen öğrencilerin interneti etik kullanım düzeyleri güvenlik, temel ilkeler, telif hakkı ve dürüstlük boyutlarını pozitif yönde etkilerken, sağlıklı internet kullanımı ve çevrimiçi nezaket boyutları açısından ise negatif yönde etkilediği görülmektedir. İnterneti yeni arkadaş edinme ve sosyal ağlarda paylaşımda bulunma amacıyla kullanan öğrencilerin interneti etik kullanım düzeyleri sağlıklı internet kullanımı ve çevrimiçi nezaket boyutlarını pozitif yönde etkilerken, temel ilkeler, dürüstlük, telif hakkı ve güvenlik boyutlarını ise negatif yönde etkilediği görülmektedir.

\section{SONUÇ VE TARTIŞMA}

Bu araştırmada Yönetim Bilişim Sistemleri ve Bilgisayar ve Öğretim Teknolojileri Eğitimi bölümünde okuyan öğrencilerin internet teknolojilerini etik kullanım düzeylerinin belirlenmesi hedeflenmiştir. Ayrıca araştırmada öğrencilerin internet teknolojilerini etik kullanımlarında cinsiyet değişkeni açısından kız öğrencilerin erkek öğrencilere göre daha etik davranışlarda bulunduğunu göstermektedir. Torun (2007) tarafından yapılan araştırmada, bayanların internet etiği tutum puanlarının erkeklere göre istatistiksel açıdan anlamlı derecede yüksek olduğunu ve kız öğrencilerin erkek öğrencilere göre daha etik tutum göstermekte olduğu sonucuna ulaşmıştır. Benzer bir şekilde Uysal (2006) araştırmasında, bayanların etik algı puanlarının erkeklere nazaran daha yüksek olduğu sonucuna ulaşmıştır. Erdem (2008) çalışmasında, kız öğrencilerin erkek öğrencilerine göre bilişim teknolojilerini daha etik kullandıkları sonucuna ulaşmıştır. Beder ve Ergün (2015) yapmış oldukları çalışmalarında internet güvenliği konusunda kız öğrencilerin erkek öğrencilere göre daha fazla bilinçli oldukları sonucuna ulaşmışlardır. Peker ve Eroğlu 
(2010) çalışmalarında, kişilerin internet bağımlılıklarının artması siber zorbalığında artmasına neden olduğunu ve aynı zamanda bu farklılığın olmasına sebep olarak ise erkeklerin bilişim teknolojilerini kızlara nazaran daha ilgi ve yakından takip etmeleri nedeniyle bu gelişmeleri kötü amaçlar doğrultusunda kullanabildiklerini göstermişlerdir. Büyükfiliz (2016), Ünver (2016) yapmış oldukları çalışmalarında erkek öğrencilerin kız öğrencilere nazaran daha fazla riskli internet kullandıkları sonucuna ulaşmıştır. Haines ve Leonard (2007) çalışmalarında etik kararlar almada cinsiyetin en güçlü faktör olduğunu belirtmişlerdir. Ayrıca Baker ve Kavşut (2007) çalışmalarında erkek öğrencilerin kız öğrencilere nazaran daha çok hem siber zorbalık yaptığını hem de siber zorbalığı maruz kaldıklarını belirtmişlerdir. Bu araştırmada erkek öğrencilerin kız öğrencilere göre daha fazla uzun süre internet teknolojilerini kullanmaları ve internet kafe gibi internete erişim sağlayabilecekleri ortamlara kız öğrencilere göre daha rahatlıkla erişim sağlamalarından kaynaklanabileceği söylenebilir.

Araştırmada öğrencilerin internete bağlı kalma süresi ile internetin etik kullanımına yönelik farkındalık düzeyleri açısında anlamlı bir farklılık görülmektedir. Meydana gelen bu farklılık Güvenlik ve Sağlıklı Internet Kullanımı boyutlarında görülmektedir. Güvenlik boyutunda internete bağlı kalma süresi arttıkça etik kullanım düzeyleri artar iken, Sağlıklı Internet Kullanma boyutunda etik kullanım düzeylerinin azaldığı görülmüştür. Aynı şekilde Zeybek (2011) ve Uysal (2006) yapmış oldukları çalışmalarında öğrencilerin bilişim teknolojilerinin kullanımlarında haftalık internete bağlı kalma sürelerine göre Fikri Mülkiyet faktörü açısından anlamlı bir farklılı̆̆ın ortaya çıktığını ve öğrencilerin internete bağlı kalma süreleri arttıkça bilişim teknolojilerini etik dışı kullanımlarının arttığı sonucuna ulaşmışlardır. Ayrıca Torun (2007) yapmış olduğu çalışmasında öğrencilerin internete bağlı kalama süreleri arttıkça internet etiği tutumlarının Telif Hakkı faktöründe olumsuzlaştığı ve aynı zamanda da internete bağlı kalma süreleri artan öğrencilerin pornografiye olan ilgilerinin de arttığı sonucuna ulaşmıştır. Ünver (2016) yapmış olduğu çalışmasında günlük 0-2 saat arasında internet kullanan öğrencilerin siber zorbalık, problemli internet kullanımı ve riskli internet kullanımı açısından puanların daha yüksek olduğu sonucuna ulaşmıştır. Ancak Gökmen ve Akgün (2014) yaptıkları çalışmada öğrencilerin günlük internet kullanım süreleri ile bilişim güvenliği bilgileri arasında herhangi bir anlamlı farklılı̆̆ın olmadığı sonucuna ulaşmışlardır. Bulgularda da görüldüğü gibi, öğrencilerin haftalık internete bağlı kalma sürelerinin artması etik dışı davranışlara yönelmelerini tetiklemektedir. Çünkü bireylerin internet ortamında geçirdikleri sürenin artması etik dışı davranışlar ile karşılaşma olasılığını arttırmakla birlikte kişilerin etik dışı davranışlarda bulunmalarına yönlendirebileceği şeklinde yorumlanabilir. 
Araştırmada, öğrencilerin ailelerinin gelir düzeyleri ile internetin etik kullanım düzeyleri açısından yalnızca Sağlıklı Internet Kullanımı boyutunda anlamlı bir farklılık görülmüştür. Öğrencilerin ailelerinin gelir seviyesi arttıkça internetin etik kullanım düzeyleri de azalmaktadır. Aynı doğrultuda Torun (2007) yapmış olduğu çalışmasında öğrencilerin ailelerinin gelir seviyesinin arttıkça, interneti etik kullanım tutumlarının olumsuzlaştı̆̆ sonucuna ulaşmıştır. Büyükfiliz (2016) ve Durak Batıgün ve Kılıç (2011) yapmış oldukları çalışmalarında ailelerin gelir seviyesi üst sosyo-ekonomik düzeyde olanların, düşük ve orta sosyo-ekonomik düzeyde olanlara göre daha fazla problemli internet kullandıkları sonucuna ulaşmıştır. Fakat Erdem (2008) yapmış olduğu çalışmasında öğretmen adaylarının ailelerinin gelir düzeyi ile bilişim teknolojilerini kullanım davranışları arasında herhangi bir faktör için anlamlı bir farklılı̆̆ın olmadığı sonucuna ulaşmıştır. Esen ve Siyez (2011)'de yapmış oldukları çalışmalarında sosyoekonomik düzey ile anlamlı bir farklılık bulunmadığı sonucuna ulaşmışlardır. Bazı çalışmalarda sosyoekonomik seviyelerinin bilişim teknolojilerini kapsayan etik ikilemler doğrultusunda alınacak kararlara etkisinin olmadığı sonucuna da ulaşmışlardır (Uysal, 2006; Gattiker ve Kelly 1999). Bu durumu ailelerinin gelir seviyesi düşük olan öğrencilerin internet teknolojilerine erişim olanakları ve kullanım imkânlarının kısıtlı olmasından kaynaklanarak etik ilkelere uyum noktasında daha yatkın olabilirler şeklinde yorumlayabiliriz.

Araştırmanın bir diğer bulgusu ise; öğrencilerin kendilerine ait kişisel bir bilgisayarı olup olmaması durumuna göre internetin etik kullanımına yönelik düzeyleri arasında anlamlı bir farklılığın olmamasıdır. Benzer şekilde Erdem (2008) yapmış olduğu çalışmasında öğretmen adaylarının kişisel bilgisayara sahip olma durumlarının bilişim teknolojilerini kullanımlarına göre hiçbir faktör için anlamlı bir farklılığın olmadığı sonucuna ulaşmıştır. Çelen (2012) yapmış olduğu çalışmasında öğrencilerin kişisel bilgisayarlarının olup olmama durumunun bilişim teknolojilerinin etik kullanımları arasında anlamlı bir farklılığın olmadığı sonucuna ulaşmıştır. Gökmen ve Akgün (2014) yaptıkları çalışmada öğrencilerin kişisel bilgisayarlarının olma durumu ile bilişim güvenliği bilgileri ile herhangi bir farklılığın olmadığı sonucuna ulaşmışlardır. Ancak Zeybek (2011) yapmış olduğu çalışmasında kişisel bilgisayara sahip olup olmama durumu toplumsal etki, bilgi doğruluğu, fikri mülkiyet ve güvenlik-kalite faktörleri açısından anlamlı bir farklılığın olduğu sonucuna ulaşmıştır. Bu durumu öğrencilerin kişisel bilgisayara sahip olanlar bilgisayar başında daha fazla vakit harcadıkları fakat kişisel bilgisayara sahip olmayanların ise istedikleri her an bilgisayara erişim sağlayamadıkları veya kısıtlı bir süre zarfında erişim sağladıklarından kaynaklanabileceği şeklinde yorumlanmıştır. 
Araştırmada, öğrencilerin web sayfası tasarlayabilme ve program yazabilme beceri düzeylerinin internetin etik kullanımına yönelik telif hakkı boyutunda anlamlı bir farklılığın olduğu bulunmuştur. Oluşan bu farklılık, programlama ve web tasarımı yapabilme beceri düzeyi hiç olmayanlar ile iyi olanlar arasında görülmektedir ve öğrencilerin program yazabilme düzeyleri yükseldikçe interneti etik kullanım düzeyleri de azalmaktadır. Elde edilen bulgular doğrultusunda, Zeybek (2011) yapmış olduğu çalışmasında öğrencilerin çeşitli programlama dillerinde program yazabilme düzeyleri ile bilişim teknolojilerini kullanımlarının tüm faktörler açısından farklılığın oluştuğu sonucuna ulaşmıştır. Ayn zamanda hiç program yazabilme bilgisi olmayan öğrenciler bilişim teknolojilerini oldukça iyi bir etik seviyede kullanırken, çok iyi program yazabilme bilgisine sahip olanların ise oldukça yüksek seviyede etik dışı kullanım sergiledikleri sonucu ortaya çıkmıştır. Ancak Zeybek (2011) öğrencilerin web sayfası tasarlayabilme seviyeleri ile bilişim teknolojilerini kullanımları arasında hiçbir faktör için anlamlı bir farklıı̆̆ın olmadığı sonucuna ulaşılmıştır. Bu araştırmalar ışığında ortaya çıkan sonucun öğrencilerin programlama bilgilerinin artması ile birlikte kendilerine olan güvenlerde de artış görülmesi etik dışı davranışlarda bulunmalarına yönlendirdiği şeklinde yorumlanabilir.

Araştırmanın diğer bir bulgusu öğrencilerin bölümlerine göre internet teknolojilerini etik kullanım düzeyleri bütün boyutlar için anlamlı bir farklılık görülmektedir. Aynı zamanda YBS bölümü öğrencilerinin interneti etik kullanım düzeyleri Temel İlkeler, Dürüstlük, Güvenlik ve Telif Hakkı boyutlarını pozitif yönde etkilerken, BÖTE bölümü öğrencilerinin ise Sağlıklı İnternet Kullanımı ve Çevrimiçi Nezaket boyutlarını pozitif yönde etkilediği görülmektedir. Benzer bulgular neticesinde, Tosun, Geçer ve Kaşıkçı (2016) yapmış oldukları çalışmalarında BÖTE bölümü öğrencilerinin internet etik algılarının yüksek düzeyde olduğu ama telif hakkı faktörüne ait ortalamalarının düşük seviyede olduğu sonucuna ulaşmışlardır.

Araştırmada öğrencilerin interneti arkadaşlarla iletişim kurma, oyun oynama, sosyal ağlarda (Facebook, Twitter vb.) paylaşımlarda bulunma, bilgi/ödev arama, yeni arkadaşlar edinme, alışveriş yapma durumlarında anlamlı bir farklılık görülmektedir. Benzer bir şekilde Karahisar (2014) yapmış olduğu çalışmasında çocukların ve gençlerin internet üzerinden tanımadıkları kişiler ile iletişim kurdukları sonucuna ulaşmıştır. VignaTaglianti vd. (2017) yapmış oldukları çalışmada erkek öğrencilerin interneti çevrimiçi oyun oynama, dosya indirme, kumar oynama ve sörf etmek için kullanırken kız öğrencilerin daha çok bilgi arama, sohbet etmek, e-posta göndermek ve sosyal paylaşımlarda bulunma için kullandıkları sonucuna ulaşmışlardır. Ayrıca Solmaz, Tekin, 
Herzem ve Demir (2013) çalışmalarında, öğrencilerin sosyal medyayı aktif kullandıklarını ve interneti yeni arkadaşlar edinmek için değil var olan arkadaşları ile iletişimde kullandıklarını belirtmişlerdir. Aynı zamanda yeni bilgi edinmek, bilgi paylaşmak, farklı kişilerle fikir alışverişlerinde bulunma, mesajlaşma gibi durumlar içinde interneti ve sosyal medya ağlarını kullandıkları sonucuna ulaşmışlardır. Şahin (2011) yapmış olduğu çalışmasında interneti oyun oynama ve sohbet etmek için tercih eden öğrencilerin internete bağımlılıklarının yüksek olduğu sonucuna ulaşmıştır. Ayas (2012) yapmış olduğu çalışmasında öğrencilerin oyun bağımlılıklarının problemli internet kullanımlarını pozitif yönde etkilediğini belirtmiştir. Ayrıca Ünver (2016) yapmış olduğu çalışmasında kişilerin interneti sosyal medya kullanımı, oyun oynama ve diğer amaçlar için tercih edenlerin yüksek oranda riskli internet kullandıkları sonucuna ulaşmıştır. Büyükfiliz (2016) yapmış olduğu çalışmasında öğrencilerin interneti oyun oynama ve diğer amaçlar için tercih edenlerin daha çok problemli internet kullandıkları sonucuna ulaşmıştır. $\mathrm{Bu}$ durumu, öğrencilerin interneti kullanım tercihlerinin aynı zamanda interneti etik kullanım düzeylerini de doğrudan etkilemektedir. Çünkü öğrenciler internet ortamında geçirdikleri zaman içerisinde maruz kaldıkları etik dışı davranışlardan etkilenerek başka kişilere bu davranışları yansıtma eğilimi görülebilmektedir. Bundan dolayı öğrencilerin interneti etik kullanım düzeylerini etkileyen unsurların interneti kullanım tercihlerini de etkilediği şeklinde yorumlayabiliriz.

\section{5. ÖNERILLER}

Araştırma sonucunda aşağıdaki önerilerde bulunulmuştur;

1.Üniversitelerde yer alan bilişim bölümlerine etik konulu dersler konulmalı ve bilgisayar içerikli derslerin müfredat programlarına da bilgisayar ve internet etiği ile ilgili konular eklenmelidir.

2.Araştırma farklı bölüm ve demografik özelliğe sahip öğrencileri de kapsayan bir çalışma yapılarak elde edilen sonuçlar karşılaştırılmalıdır.

3.Uygulanan "Internet Etik Kullanım Ölçeği” farklı toplum, kültür, inanç, bilgisayar kullanım yeterliliği, öz güven gibi bağımsız değişkenler eklenerek öğrencilerin internetin etik kullanım düzeyleri karşılaştırılmalıdır. 
4.Siber zorbalık, bilişim suçları gibi boyutlar eklenerek ölçek geliştirilebilir.

\section{KAYNAKÇA}

Çelen, F. K. (2012). Bilgi ve İletişim Teknolojilerinin Kullanımında İlköğretim Öğrencilerinin Etik Olmayan Davranışlara İlişkin Görüşlerin İncelenmesi.

Çetinkaya, B. (2010). İlköğretim ikinci kademe öğrencilerinde siber zorbalığın yaygınlığı. Yüksek Lisans Tezi. Konya: Selçuk Üniversitesi Eğitim Fakültesi Enstitüsü.

Özaydın, B. (2010). Teknoloji Kültürü ve Etik. Isparta, Türkiye: Süleyman Demirel Üniversitesi Fen Bilimleri Enstitüsü.

Adam, A. (2000). Gender and Computer Ethics. Computers and Society, 17-24.

Arıcak, O. T. (2009). Üniversite Öğrencilerindeki Siber Zorbalık Davranışlarının Bir Yordayıcısı Olarak Psikiyatrik Belirtiler. Eurasian Journal of Educational Research, 167184.

Arıcak, O. T. (2011). Siber Zorbalık: Gençlerimizi Bekleyen Yeni Tehlike. Kariyer Penceresi, $10-12$.

Arslan, Z. (2003). ABD Yüksek Mahkemesi Kararlarında İfade Özgürlüğ̈̈, Liberal Düşünce Topluluğu. Ankara: Avrupa Komisyonu Cantekin Matbaası.

Ayas, T. (2012). Tle Relationship Between Internet and Computer Game Addiction Level and Shyness Among High School Student. Educational Sciences: Theory and Practice, 632-636.

Büyüköztürk, Ş. (2017). Sosyal Bilimciler İçin Veri Analizi El Kitabı. Ankara: Pegem Akaddemi.

Büyükfiliz, B. (2016). 18-25 Yaş Arası Genç Yetişkinlerde Problemli İnternet Kullanımı ve İletişim Becerileri Arasındaki İlişki. Yüksek Lisans Tezi. İstanbul: Üsküdar Üniversitesi Sosyal Bilimler Enstitüsü.

Baker, Ö., \& Kavşut, F. (2007). Akran Zorbalığının Yeni Yüzü: Siber Zorbalık. Eurasian Journal Of Educational Research, 31-42.

Baloğlu, Ç. (2006). İfade Özgürlüğü. Kocaeli: Kocaeli Üniversitesi Sosyal Bilimler Enstitüsü. Beder, A., \& Ergün, E. (2015). Ortaokul Öğrencilerinin Güvenli İnternet Kullanım Durumlarının Belirlenmesi. Ĕ̆itim Bilimleri ve Uygulama, 23-41.

Cerrah, İ. (2001, Mart 24). Bilişim teknolojileri ve etik. Bilişim ve internet teknolojilerinin ceza hukuku açısından doğurduğu yeni sorunlar. (s. 15-29). Bursa: Türkiye Cumhuriyeti İçişleri Bakanlığı.

Dülger, M. V. (2004). Avrupa İnsan Hakları Sözleşmesi'nde Düşünce Özgürlüğü. İstanbul: Galatasaray Üniversitesi Yayını.

Dedeoğlu, G. (2001). Etik ve Bilişim. Ankara: Türkiye Bilişim Derneği Yayınları.

Dedeoğlu, G. (2006). Bilişim Toplumu ve Etik Sorunlar. Bursa: Alfa Aktüel Yayınları. 
Durak Batıgün, A., \& Kılıç, N. (2011). İnternet Bağımlılı̆̆ı: Kişilik Özellikleri, Psikolojik Belirtiler, Sosyal Destek ve İlişkili Bazı Sosya-demografik Değişkenler Arasındaki İlişkiler. Türk Psikoloji Dergisi, 1-10.

Erdem, Z. (2008). Öğretmen Adaylarının Bilişim Teknolojilerini Kullanımlarının Etik Açıdan Değerlendirilmesi. Dokuz Eylül Üniversitesi Eğitim Bilimleri Enstitüsü.

Ersoy, A., \& Özden, M. (2011). Öğretmen Adaylarının Ödevlerinde İnternetten İntihal Yapmlarında Öğretim Elemanının Rolüne İlişkin Görüşleri. İlköğretim Online, 608619.

Esen, E., \& Siyez, D. M. (2011). Ergenlerde İnternet Bağımlılı̆̆ını Yordayan Psiko-sosyal Değişkenlerin İncelenmesi. Türk Psikolojik Danışma ve Rehberlik Dergisi, 127-138.

Fidan, M. (2016). Bilişim Etiği Boyutlarına Göre Bilişim Teknolojileri Ve Yazılım Dersi Öğretim Programı Kazanımlarının İncelenmesi. Kastamonu Ĕ̆itim Dergisi, 1641-1654.

Gökmen, Ö. F., \& Akgün, Ö. E. (2014). Bilgisayar ve Öğretim Teknolojileri Eğitimi Öğretmen Adaylarının Bilişim Güvenliği Bilgilerinin Çeşitli Değişkenlere Göre İncelenmesi. Çukurova Üniversitesi Ĕ̆itim Fakültesi Dergisi, 61-84.

Gattiker, U. E., \& Kelley, H. (1999). Morality And Computer: Attitudes And Differences In Moral Judgments. Information Systems Research, 233-254.

Genç, Z., Kazez, H., \& Fidan, A. (2013). Çevrimiçi Etik Dışı Davranışlarının Belirlenmesi İçin Bir Ölçek Uyarlama Çalışması,. Akademik Bilişim 2013 (s. 194-197). Antalya: Akdeniz Üniversitesi.

Haines, R., \& Leonard, L. K. (2007). Individual Characteristics and Ethical Decisionmaking in an IT context. Journal of Management \& Data Systems, , 5-20.

Ünver, H. (2016). Siber Zorbalık ile Problemli İnternet Kullanımı ve Riskli Internet Davranışı Arasındaki İlişki ve Bu Değişkenlerin Çeşitli Demografik Özellikler Açısından İncelenmesi. Yüksek Lisans Tezi. Ankara: Gazi Üniversitesi Eğitim Bilimleri Enstitüsü.

Karagöz, K. (2004). İfade Özgürlüğü ve İnsan Hakları Avrupa Mahkemesi Kararlarında Sınırlandırılması Sorunu. Ankara, Türkiye: Ankara Üniversitesi Sosyal Bilimler Enstitüsü.

Karahisar, T. (2014). İnternette Çocukları Bekleyen Riskler ve Medya Okuryazarlığı. The Turkish Online Journal of Design, Art and Communication, 82-95.

Karasar, N. (2004). Bilimsel Araştırma Yönetmi. Ankara: Nobel Yayınları.

Kavza, U. (2010). Veri Madenciliğinde Mahremiyetin Sağlanması. Yüksek Lisans Tezi. Kocaeli: Gebze Yüksek teknoloji Enstitüsü Mühendislik ve Fen Bilimleri Enstitüsü.

Kazaskeroğlu, E., Özpınar , A., \& Öz, Ö. (2010). Bilgiye Erişim, Paylaşım Ve Bilgi Teknolojileri Alanında Etik Olmayan Davranışlar Ve Sebepleri. Ankara, Türkiye: III. A $\breve{g}$ ve Bilgi Güvenliği Sempozyumu.

Kiera, J., \& Cronan, T. (1998). How Men And Woman View Ethics. Communications Of The ACM, 70-76. 
Kuzu, E. B., \& Becit, G. (2008). Bilgisayar Etiği Bilgisayar ve Öğretim Teknolojileri Eğitimi Programlarinda Kendine Ne Kadar Yer Buluyor?,. 8th International Education Technology Conference, (s. 284-288). Eskişehir.

Lau, W., \& Yuen, A. (2014). Internet Ethics Of Adolescents: Understanding Demographic Differences. Computer $\mathcal{E}$ Education, 378-385.

Mason, R. O. (1986). Four Ethical Issues of Information Age. Mis Quarterly, 5-11.

Metin, M. (2015). Kuramdan Uygulamaya Ĕ̆itimde Bilimsel Araştırma Yöntemleri. Ankara: Pegem Yayınlar1.

Peker, A., \& Eroğlu, Y. (2010). Erkek Öğrencilerde Siber Zorba ve Kurban Olmanın Yordayıcısı Olarak İnternet Bağımlılı̆̆ı. 4. Uluslararası Bilgisayar ve Öğretim Teknolojileri Sempozyumu (s. 862-867). Konya: Maya Akademi.

Perry, B. (2010). Exploring Academic Misconduct: Some Insights Into Student Behaviour. Active Learning In Higher Education, 97-108.

Solmaz, B., Tekin, G., Herzem, Z., \& Demir, M. (2013). İnternet ve Sosyal Medya Kullanımı Üzerine Bir Uygulama. Selçuk İletişim, 23-32.

Şahin, C. (2011). An Analysis of Internet Addiction Levels of Individuals According to Various Variables. The Turkish Online Journal of Education Technology, 60-66.

Türk Ceza Kanunu. (2004). http://www.tbmm.gov.tr/kanunlar/k5237.html adresinden alınd 1

Türk Patent Enstitüsü. (2013). Fikri Mülkiyet ve Küçük Orta Ölçekli İşletmler. http://www.turkpatent.gov.tr/dosyalar/yayinlar/bilgikitapciklari/fikrimlkytkobi.pdf adresinden alınd 1

Takemura, T., Tanaka, H., \& Matsuura , K. (2011). Analysis of Awareness Gap between Security Managers and Workers in an Organization with Regard to the Effectiveness of the Informations Security Measures. Journal of Information Prowessing, 253-262.

Torun, Ö. (2007). Resmi Ortaokul Kurumlarında Öğrenim Gören Öğrencilerin İnternet Etiğine İlişkin Algılarının İncelenmesi. MArmara Üniversitesi Eğitim Bilimler Enstitüsü.

Tosun, N., Geçer, A., \& Kaşıkçı, D. N. (2016). Öğretmen Adaylarının Internet Etiği Algıları ve Kontrol Odağı Algıları Arasındaki İlişkinin İncelenmesi. Açıköğretim Uygulamaları ve Araştırmaları Dergisi, 2(4), 82-103.

Uysal, Ö. (2006). Öğretmen Adaylarının Bilgisayar Etiğine İlişkin Görüşleri. Eskişehir: Anadolu Üniversitesi Eğitim Bilimleri Enstitüsü.

Vigra-Taglianti, F., Brambilla, R., Priotto, B., Angelino, R., Cuomo, G., \& Diecidue, R. (2017). Problemmatic Internet Use Among High School Student: Prevalence,Associated Factors and Gender Differences. Psychiatry Research, 163-171.

Zeybek, G. (2011). Bilgisayar Meslek Dersi Alan Ortaöğretim Öğrencilerinin Bilişim Teknolojilerini Kullanımlarının Etik Açıdan İncelenmesi. Konya. 
